\title{
FLOYD, Rita. Security and the Environment: Securitisation Theory and US Environmental Security Policy. Cambridge University Press, 2010. ISBN: 9780521197564
}

\section{ANA BÁRBARA MOREIRA TESCHE*}

O livro "Security and the Environment: Securitisation Theory and US Environmental Security Policy” (Cambridge: Cambridge University Press, 2010), é o primeiro a reunir de forma abrangente o tema da segurança ambiental e a teoria da securitização desenvolvida pela escola de Copenhague. Rita Floyd, PhD em Relações Internacionais pela Universidade de Warwick e mestre em Política pela Universidade de Edimburgo, atualmente é fellow do Instituto de Segurança Ambiental e pós-doutoranda no Departamento de Política e Estudos Internacionais da Universidade de Warwick, no Reino Unido. Sua área de especialização em estudos de segurança tem um foco particular em segurança ambiental ${ }^{1}$.

Floyd tem por objetivo fazer uma reformulação da teoria de securitização e torná-la mais atraente. Usando o exemplo dos Estados Unidos, suas políticas de segurança ambientais, sob as administrações Clinton e Bush de 1993 a 2009, a autora permite insights sobre as intenções dos atores securitizadores, buscando fazer uma avaliação moral da securitização e dessecuritização no setor ambiental de segurança. A análise empírica se baseia em inúmeras entrevistas originais com políticos e ex-políticos envolvidos na segurança ambiental dos Estados Unidos.

A teoria da securitização sustenta que, nas relações internacionais, um determinado ponto torna-se uma questão de segurança, não quando algo constitui uma ameaça para o Estado ou para alguma outra entidade, mas quando um ator securitizador argumenta que algo constitui uma ameaça existencial a algum objeto, que precisa ser tratada de imediato, se o objetivo é sobreviver. Partindo do pressuposto que a segurança internacional é uma prática "self-referential", ou seja, dependente unicamente dela mesma para existir, e apenas faz sentido dentro de sua própria lógica, Floyd argumenta que um mesmo conceito pode significar coisas completamente

\footnotetext{
* Bacharel em Relações Internacionais (UNILASALLE) e mestranda em Ciência Política pela Universidade Federal do Rio Grande do Sul (UFRGS). Membro do grupo de Segurança e Política Internacional.

1. Informações extraídas da página virtual da autora no sítio do Institute for Environmental Security. http://www.envirosecurity.org/about/people/rfloyd.php. Acessado em 17/04/2013.
} 
diferentes dentro da teoria. Os teóricos da securitização parecem concordar sobre a importância tanto da securitização como da dessecuritização, argumentando que, em determinadas circunstâncias, a securitização pode ser encarada como moralmente errada e a dessecuritização como moralmente correta, dependendo dos efeitos ou conseqüências da ação dos atores securitizadores.

No primeiro capitulo, a autora faz uma análise da teoria da securitização. Passando por autores como John L. Austin, Jacques Derrida, Carl Schmitt e Kenneth Waltz, Floyd pretende demonstrar a influência destes como antecessores de tal teoria. Uma análise do realismo pós-estrutural e suas fraquezas normativas também são feitas, bem como a análise da coerência da teoria de securitização ao longo do tempo.

No capitulo dois, desenvolve sua própria teoria da securitização revisada. Ao contrário da Escola de Copenhague, a securitização existiria, não quando o público aceita a justificativa de uma determinada ameaça existencial, mas quando há uma mudança de comportamento relevante do agente, justificada por este mesmo agente, com referência a tal ameaça. Securitização consiste em dois eventos: justificação de uma ameaça existencial (o movimento de securitização) e a subseqüente prática da segurança. Em sua revisão da teoria, a autora propõe os seguintes pontos: (a) Securitizações são bem sucedidas simplesmente em virtude de existir, e não no momento em que as regras normalmente obrigatórias estão sendo quebradas e medidas de emergência estão sendo tomadas. (b) Dessecuritização é entendida como o processo onde a securitização é então revertida para "fora da esfera de emergência”, passando a existir uma politização. Floyd argumenta que possa existir uma dessecuritização seguida de despolitização. A partir destes dois pontos, a autora enumera que existem: (1) Dois tipos de securitização em termos de quem, ou de que, eles possam se beneficiar, e (2) dois tipos de dessecuritização, o que nos permitiriam pensar a securitização como moralmente correta e moralmente errada no setor ambiental.

O capítulo três é o primeiro de três capítulos empíricos que visam testar a teoria de securitização revista. Analisa o surgimento da segurança ambiental no contexto dos EUA e localiza o movimento de securitização. O termo "Segurança ambiental" foi mencionado pela primeira vez na $\mathrm{Na}$ tional Security Strategy, em 1991, e, mais tarde, sob a administração Clinton, tornou-se uma parte intrínseca do vocabulário dos líderes e funcionários do governo dos EUA, sendo a questão posteriormente securitizada.

O quarto capítulo investiga o que aconteceu com a segurança ambiental 
além do reconhecimento retórico pelos tomadores de decisão relevantes. Para a autora, a justificativa de uma ameaça existencial não foi acompanhada pela prática de segurança, e que o beneficiário da securitização não era o objeto referente de segurança (neste caso, o povo americano), mas, em vez disso, foi o próprio ator securitizador que beneficiou-se da segurança ambiental.

No capítulo cinco, examina o que aconteceu com as várias políticas ambientais de segurança no âmbito dos dois governos de George W. Bush de 2001 a 2009. A autora argumenta que este estudo de caso é um exemplo de “dessecuritização como despolitização”, uma vez que as questões consideradas de segurança ambiental não mais foram consideradas como questões de segurança, mas elas desapareceram como um todo da agenda política desta administração.

No sexto capitulo, faz uma avaliação moral da securitização e dessecuritização no setor ambiental de segurança. A partir da Escola de Copenhagen, propõe que a securitização não tem valor intrínseco. O que importa são as conseqüências da securitização em si. A autora propõe um foco nas conseqüências, o que, em filosofia moral, corresponde a uma ética consequencialista. Consequencialistas sustentam que a coisa certa a se fazer, em qualquer situação, é agir com vistas a maximizar as melhores conseqüências. O que consequencialistas acreditam serem as melhores consequências depende da unidade de valor que eles endossam.

Juntamente com a maioria dos consequencialistas, a autora endossa o bem-estar do ser humano como o mais alto valor, e argumenta que um funcionamento natural do ambiente não humano é um requisito necessário para o bem-estar humano, argumentando, então, que apenas a segurança ambiental como segurança humana é moralmente permissível, pois, apenas neste quadro, seres humanos são considerados os beneficiários das políticas de segurança. Outras abordagens da segurança ambiental (segurança ambiental como de segurança nacional e segurança ecológica), que promovem diferentes objetos referentes de segurança ambiental, ficam enquadradas como moralmente insustentáveis. No que diz respeito à dessecuritização, a idéia de que o meio ambiente é instrumentalmente valioso para fins humanos, significa que dessecuritização como politização é moralmente correta, como também a preservação e proteção do ambiente global exigem uma liderança política de alto nível.

Em suma, o livro traz como principal contribuição uma ampla análise acerca da segurança ambiental nos governos Clinton e Bush, e como ocor- 
reram processos de securitização e despolitização. Apesar dessa ampla análise, o link entre a abordagem abrangente da Escola de Copenhagen e uma perspectiva de teoria política ou filosofia moral, merece mais atenção, uma vez que a teoria da securitização trata a segurança nacional como principal fundamento, e uma perspectiva de filosofia moral trataria o individuo como principal foco, remetendo muito mais à chamada segurança humana do que ao conceito de segurança nacional.

Recebido em: 14/05/2013. Aprovado em: 10/07/2013. 